\title{
MOŽNÉ SOUVISLOSTI MEZI BLÍZKÝMI VZTAHY VYSOKOŠKOLSKÝCH STUDENTŮ, VNÍMÁNÍM STRESU A POUŽíVÁNÍM COPINGOVÝCH STRATEGIÍ1
}

\author{
MGR. MARTINA RoĎANOVÁ2, \\ DOC. MGR. LENKA LACINOVÁ, PH.D.2,3
}

\begin{abstract}
Abstrakt: Výzkumná studie mapovala vztahy mezi citovou vazbou v mladé dospělosti, stresem a jeho zvládáním. Konkrétním cílem práce bylo prověrit souvislost mezi vyhýbavostí/úzkostností v citové vazbě, repertoárem copingových strategií a vnímáním stresu. Dále byl prozkoumán i vztah citové vazby a flexibility ve zvládání stresu. Sledovanou populací byli vysokoškolští studenti ve věku 19-30 let, výzkumný soubor tvořilo 417 respondentů. Výzkum byl realizován pomocí Dotazníku struktury vztahů (ECR-RS, Fraley et al., 2011), Škály flexibility ve zvládání stresu (CFS; Kato, 2012) a vlastní metody, která se sestávala ze 6 vinět popisujících stresové situace. Pomocí regresních analýz byl potvrzen pozitivní vztah mezi mírou vyhýbavost ve vztahu $k$ rodičùm a rozsahem repertoáru copingových strategií a negativní vztah mezi mírou vyhýbavosti ve vztahu k otci a využíváním adaptivního copingu jako složky copingové flexibility. $V$ rámci mediačních analýz se nepodařilo prokázat, že je repertoár copingových strategií mediátorem vztahu mezi citovou vazbou a vnímáním stresu.
\end{abstract}

Klíčová slova: citová vazba v dospělosti, úzkostnost, vyhýbavost, vnímání stresu, coping

\section{Úvod}

Bowlby (1969/2010) pojímá citovou vazbu jako emoční pouto k určité osobě, kterou má dítě tendenci vyhledávat nebo pobývat v její blízkosti, a to zejména v situacích, kdy je vylekané, unavené nebo nemocné. Tato tendence je chápána jako biologická predispozice a její interakcí vytvořená specifická podoba se $\mathrm{v}$ čase mění jen velmi pomalu a není ovlivněna okamžitou situací. Již samotný autor poukázal na to, že tendence utvářet si pouto $\mathrm{k}$ druhé osobě se nevztahuje pouze kobdobí dětství, ale v různých podobách provází jedince celým životem. V dospělosti je citová vazba často

\footnotetext{
${ }^{1}$ Text vznikl na základě př́spěvku prezentovaného na konferenci Psychologická diagnostika: Výzkum, prevence a poradenství, konané v Brně 19.-21. 6. 2013 (http://psychodiagnostika.fss.muni.cz/2013).

${ }^{2}$ Katedra psychologie, Fakulta sociálních studií MU, Joštova 10, 602 00, Brno

${ }^{3}$ Institut výzkumu dětí, mládeže a rodiny, Fakulta sociálních studií MU, Joštova 10, 60200 Brno
} 
reciproční, osoby poskytují péči a ochranu navzájem a jsou si vzájemnými vazbovými osobami.

Někteří autoři (např. Brennan, Clark, \& Shaver, 1998) nahlíží na citovou vazbu ve dvou dimenzích - úzkostnost a vyhýbavost. Na dimenzionálním pojetí je v současné době založeno několik metod určených ke zjišt'ování citové vazby (např. ECR-RS) a bylo využito i při realizaci této studie.

S úzkostností se pojí hyperaktivační strategie, která je charakterizována citlivostí k možnému ohrožení. Jedinci, kteří ji využívají, jsou přesvědčeni, že situaci sami nezvládnou. To pak může vést k opakovanému vyhledávání blízkosti a zvýšené potřebě získat partnerovu pozornost, péči a podporu. Úzkostné osoby často zapojují toto chování, i když neexistuje objektivní ohrožení. Tito jedinci se snaží minimalizovat kognitivní, emocionální i fyzické odloučení od partnera (Mikulincer \& Shaver, 2007).

Jedinci s vyšší mírou vyhýbavosti často využívají deaktivační strategii. Ta spočívá v odvedení pozornosti od ohrožení a potlačení myšlenek spojených s ohrožením, které by mohly aktivovat systém citové vazby. Na základě toho se vyhýbaví jedinci odklání od myšlenek na ochranu poskytovanou druhými a nepřipouští si ani myšlenky na možnou úlevu, kterou by mohla přinést blízkost s druhými. Vyhledávání blízkosti je tak utlumeno. Jedinci využívající této strategie se snaží co nejvíce maximalizovat odstup od partnera a vyhýbají se intimitě a sebeodhalení před partnerem a zároveň se snaží potlačit myšlenky o vlastní nedostatečnosti a zranitelnosti. Jejich mentální nastavení pak ovlivňuje vnímání informací o okolí, vlastní osobě i o opravdové dostupnosti vazbové postavy (Mikulincer \& Shaver, 2007).

\section{Vztah citové vazby, repertoáru copingových strategií a vnímání stresu}

Buelow, Lyddon a Johnson (2002) ve svém výzkumu našli spojitost mezi citovou vazbou v dospělosti a množstvím zdrojů ke zvládání stresu. Regresní analýza ukázala, že jistá citová vazba k partnerovi predikovala větší množství zdrojů ke zvládání stresu, vedle toho byl významným prediktorem i vztah s rodiči. Proto se lze tedy domnívat, že když mají lidé s jistou citovou vazbou k dispozici více zdrojů zvládání, budou také využívat více copingových strategií. I Mikulincer a Shaver (2007) ve svém textu uvádí, že pokud je vazbová osoba hodnocena jako dostupná, podporující a odpovídající na potřeby jedince (což je důležité pro jistou citovou vazbu), tak toto hodnocení je podkladem pro vytvoření reservoáru užitečných informací o zvládání stresových situací. Osoby s jistou základnou mají podle autorů k dispozici např́klad rozpoznání distresu či jeho přiměřenou komunikaci, vyhledávání intimity a podpory a také instrumentální řešení problému.

Studie Smidtové, Nachtigalla, Wuethrich-Martoneové a Strausse (2002) se zabývala tím, jak citová vazba u pacientů se závažnou nemocí ovlivňuje používání copingových strategií. Bylo zjištěno, že lidé s nejistou citovou vazbou jsou méně flexibilní v používání copingových strategií. $V$ pojetí autorů znamenala flexibilita zvládání stresu celkový počet 
použitých copingových strategií. Přestože se jedná o specifický klinický vzorek, autoři studie se domnívají, že tento efekt bude platit i u zdravých jedinců.

Mikulincer a Shaver (2007) ve svém textu uvádí, že lidé nejistí v citové vazbě, at' už v dimenzi úzkostnosti nebo vyhýbavosti, hodnotí stresující situace intenzivněji a jako více ohrožující a prožívají více distresu. I výsledky studie Reinerové, Andersonové, Hallové a Halla (2010) ukázaly, že úzkostnost i vyhýbavost v citové vazbě k partnerovi predikují vnímání stresu. McCarthy, Mollerová a Foulandi (2001) ve své studii zjistili, že i citová vazba ve vztahu k matce a otci souvisí s vnímáním stresu. Uvádí, že jedinci, kteř́ mají bližší a jistější vztah s rodiči, hodnotí situace jako méně stresující. Lazarus a Folkmanová (1984) poukazují na to, že na stupni stresu a síle emocionální reakce se podílí posouzení samotné situace (zda je pro člověka irelevantní, pozitivní-neškodná nebo stresující; primární zhodnocení) i posouzení copingových možností daného jedince. Na základě jejich teorie lze tedy předpokládat, že pokud bude mít člověk k dispozici více strategií, které může použít, bude hodnotit situace jako méně stresující, jelikož má $\mathrm{k}$ dispozici další možnosti, pokud se jedna z nich neosvědčí. Nepř́mým důkazem pro to, že využívání více copingových strategií vede k vnímání situace jako méně stresující, může být výsledek výzkumu (Galatzer-Levy, Burton, \& Bonnano, 2012), který poukazuje na pozitivní vztah mezi větším množstvím copingových strategií a resiliencí. Další studie (Roussi, Krikeli, Hatzidimitriou, \& Koutri, 2007) poukázala na to, že zapojení více copingových strategií u žen s rakovinou predikuje méně distresu v budoucnu.

\section{Citová vazba v souvislosti s flexibilitou ve zvládání stresu}

Flexibilita ve zvládání stresu byla definována jako schopnost hodnotit efektivitu použité copingové strategie a přerušit ji, pokud se ukázala jako neefektivní (evaluativní coping), a najít místo ní jinou strategii a tu aplikovat (adaptivní coping; Kato, 2012). Podle výsledků studie Katoa (2012) flexibilita ve zvládání stresu pozitivně souvisí s kognitivní flexibilitou. Mikulincer (1997) dále poukázal na vztah mezi citovou vazbou a kognitivní flexibilitou. Výsledky jeho studie ukázaly, že nejistí jedinci jsou méně tolerantní knejednoznačnosti a nevyzpytatelnosti informací a jejich přesvědčení jsou více dogmatická, rigidní a neměnná i v konfrontaci s protichůdnými informacemi. Jistota v citové vazbě naopak podporovala aktivní vyhledávání a otevřenost novým informacím a flexibilitu používání kognitivních schémat. Na základě Mikulincerových závěrů, že jsou jistí jedinci kognitivně flexibilnější, a souvislosti kognitivní a copingové flexibility zjištěné Katoem se lze tedy domnívat, že spolu budou pozitivně souviset i jistota v citové vazbě a copingová flexibilita.

Proces flexibility ve zvládání stresu v sobě předpokládá, aby měl jedinec $\mathrm{k}$ dispozici více copingových strategií a zdrojů (Kato, 2012). Těch mají podle výše uvedených studií (Buelow et al., 2002; Smidtová et al., 2002) více jedinci s jistou citovou vazbou. Jistí jedinci mají podle Ognibeneho a Collinsové (1998) také silnější jak osobní zdroje ke zvládání stresu (např. mají větší pocit vlastní hodnoty, kompetence a efektivity), tak i zdroje interpersonální (bližší vztahy s druhými, podporující sociální sít'). Proto by 
podle těchto autorů měli být flexibilnější v používání zvládacích strategií oproti nejistým jedincům, kterým chybí jeden nebo více těchto zdrojů. Lze tedy předpokládat, že pokud bude člověk více věřit ve vlastní schopnosti, méně o sobě pochybovat (nízká úzkostnost) a zároveň si bude schopen $v$ případě potřeby říci o pomoc ostatním (nízká vyhýbavost), nebude mu dělat obtíže změnit nefunkční strategii a vyzkoušet jinou, není totiž limitován omezeným počtem zdrojů ke zvládání stresu.

Na základě uvedených poznatků byly stanoveny následující předpoklady:

1. Úzkostnost stejně jako vyhýbavost v citové vazbě (k partnerovi, matce, otci) negativně souvisí s repertoárem copingových strategií.

2. Srostoucí úzkostností/vyhýbavostí v citové vazbě se zmenšuje repertoár copingových strategií a tím dochází k vnímání situací jako více stresujících.

3. Jak s rostoucí úzkostností, tak s rostoucí vyhýbavostí v citové vazbě klesá flexibilita copingu.

\section{Metody}

\section{Výzkumný soubor}

Výzkumu se zúčastnilo 417 vysokoškolských studentů ve věku 19-30 let (78,4 \% žen; průměrný věk: 22,$74 ; \mathrm{SD}=2,06$ ), kteří byli minimálně 4 měsíce v partnerském vztahu. Respondenti byli osloveni pomocí sociální sítě, elektronické vývěsky Masarykovy univerzity, na nástěnce Vysoké školy báňské - Technické univerzity Ostrava, Univerzity Pardubice a na diskusním fóru Vysokého učení technického v Brně. Výzkum byl realizován on-line pomocí internetových stránek www.vyplnto.cz.

\section{Metody sběru dat}

\section{Vnímání stresu a repertoár copingových strategií}

Pro zmapování toho, jaká je obecná dispozice respondentů k vnímání stresu a jaký je jejich repertoár copingových strategií, byla sestavena vlastní metoda - soubor vinět. Respondentům bylo předloženo 6 popisů stresujících událostí. U každé z nich měli určit, jak moc je pro ně daná situace stresující, výsledná proměnná vnímání stresu je pak průměrem vycházejícím z hodnocení konkrétních situací. Dále měli respondenti a z nabídnutého seznamu vybrat možnosti, kterými by se pokusili danou situaci zvládnout. V nabídce bylo celkem 13 strategií: řešení problému, vyhledání sociální opory - emocionální, vyhledání sociální opory - instrumentální, ventilace emocí, vyčkávání, fantazijní únik, sociální izolace, vyhýbání se problému, rozptýlení, akceptace, popření, kognitivní restrukturace a rezignace. Proměnná repertoár copingových strategií zahrnuje všechny strategie, jež má jedinec k dispozici např́č situacemi - využil je alespoň v jednom případě ze šesti nabízených situací ( $v$ př́padě zájmu o bližší informace o tvorbě metody či její přesné znění kontaktujte autorky textu). 


\section{Flexibilita ve zvládání stresu}

Pro zjištění flexibility ve zvládání stresu byla zvolena Škála flexibility ve zvládání stresu (CFS; Kato, 2012). Ta obsahuje 10 položek, které spadají do dvou dimenzí evaluativního a adaptivního copingu. K jednotlivým výrokům se respondenti vyjadřují na čtyřbodové škále (zcela vystihuje - nevystihuje). Tato škála byla v rámci výzkumu přeložena z anglického jazyka do češtiny.

\section{Citová vazba v dospělosti}

Citová vazba byla zjišt'ována pomocí Dotazníku struktury vztahů (ECR-RS; Fraley, Heffernan, Vicary, \& Brumbaugh, 2011). Původně bylo do dotazníku vybráno 10 položek, na základě faktorové analýzy byla však jedna vyřazena, protože měla vysoké hodnoty v obou dimenzích (vyhýbavosti i úzkostnosti). Desetipoložková verze dotazníku byla použita i v této práci. Faktorová analýza na datech 417 respondentů však potvrdila závěry autorů dotazníku, že desátá položka zřetelně nespadá ani do jedné dimenze. $\mathrm{Z}$ toho důvodu byla tato položka po vzoru autorů metody vyloučena $\mathrm{z}$ dalšího zpracování. Dotazník se tedy skládá z devíti položek, které se opakují ve vztahu k matce, otci, partnerovi a př́teli/přítelkyni (poslední vztah však nebyl předmětem výzkumu, proto nebyla sada otázek ve vztahu k přátelům použita). Do dimenze vyhýbavost patří šest položek a do dimenze úzkostnosti pak tři. Na každou z nich měli odpovědět pomocí sedmibodové škály (silně nesouhlasím-silně souhlasím).

\section{Výsledky}

K ověření stanovených předpokladů byla využita metoda regresní analýzy. Úzkostnost ve vztahu k matce, otci ani partnerovi se neukázaly jako statisticky významné prediktory repertoáru copingových strategií. V případě vyhýbavosti se však jako statisticky významným prediktorem repertoáru copingových strategií ukázala vyhýbavost ve vztahu k matce $(\beta=0,12, p<0,05)$ a vyhýbavost ve vztahu $\mathrm{k}$ otci $(\beta=0,13, p<0,05)$. Obě proměnné však repertoár predikovaly v opačném směru, než jak se předpokládalo. Ukázalo se totiž, že s rostoucí vyhýbavostí se repertoár zvětšuje. Pro úplnost, vyhýbavost ve vztahu k partnerovi nebyla statisticky významným prediktorem množství copingových strategií. Regresní koeficienty pro všechny prediktory jsou uvedeny v tabulce 1 .

K ověření předpokladu, že repertoár copingových strategií je mediátorem vztahu mezi citovou vazbou a vnímáním stresu, byl použit postup mediační analýzy podle Barona a Kennyho (1986, cit. dle Kenny, 2012). Ani v jednom prŕípadě však Sobelův test neprokázal, že repertoár mediuje vztah mezi citovou vazbou a vnímáním stresu.

V dalších analýzách bylo zjištěno, že úzkostnost stejně tak jako vyhýbavost ve vztahu k matce, otci ani partnerovy nepredikuje míru evaluativního copingu. Neprokázal se vztah ani mezi úzkostností ve vztahu k matce, k otci ani k partnerovi a adaptivním copingem. Naopak statisticky významným prediktorem adaptivního copingu se ukázala vyhýbavost ve vztahu k otci $(\beta=-0,14, p<0,05)$, s rostoucí mírou vyhýbavosti klesala míra využití adaptivního copingu. Vyhýbavost ve vztahu k matce ani k partnerovi nebyly 
TESTFÓRUM, 2015, č. 6, s. 4-13

www.testforum.cz

M. Rod’anová \& L. Lacinová: Možné souvislosti mezi blízkými vztahy vysokoškolských studentů, vnímáním stresu a používáním copingových strategií

statisticky významnými prediktory adaptivního copingu. Regresní koeficienty pro všechny prediktory jsou uvedeny v tabulce 1 . 
M. Rod’anová \& L. Lacinová: Možné souvislosti mezi blízkými vztahy vysokoškolských studentů, vnímáním stresu a používáním copingových strategií

Prověřován byl také vztah mezi repertoárem copingových strategií a flexibilitou ve zvládání stresu. Ukázalo se, že repertoár nesouvisel $\mathrm{s}$ evaluativním copingem $(\mathrm{r}(363)=0,00, n$. s. $)$. Vztah nebyl prokázán ani mezi repertoárem a adaptivním copingem $(\mathrm{r}(367)=0,03, n$. s.). Lze tedy konstatovat, že repertoár copingových strategií nesouvisel s flexibilitou ve zvládání stresu.

\section{Tabulka 1}

Regresní koeficienty zobrazující vztah mezi citovou vazbou a repertoárem copingových strategií, evaluativním copingem a adaptivním copingem

\begin{tabular}{lcccccc}
\hline & $\begin{array}{c}\text { Úzkost. } \\
\text { ve vztahu } \\
\text { k matce }\end{array}$ & $\begin{array}{c}\text { Úzkost. } \\
\text { ve vztahu } \\
\text { k otci }\end{array}$ & $\begin{array}{c}\text { Úzkost. } \\
\text { ve vztahu } \\
\text { k partnerovi }\end{array}$ & $\begin{array}{c}\text { Vyhýb. } \\
\text { ve vztahu } \\
\text { k matce }\end{array}$ & $\begin{array}{c}\text { Vyhýb. } \\
\text { ve vztahu } \\
\text { k otci }\end{array}$ & $\begin{array}{c}\text { Vyhýb. } \\
\text { ve vztahu } \\
\text { k partnerovi }\end{array}$ \\
\hline $\begin{array}{l}\text { repertoár } \\
\text { cop. strategí }\end{array}$ & $-0,03$ & $-0,003$ & $-0,006$ & $0,12^{*}$ & $0,13^{*}$ & $-0,005$ \\
$\begin{array}{l}\text { evaluativní } \\
\text { coping }\end{array}$ & 0,04 & $-0,06$ & $-0,04$ & 0,03 & $-0,06$ & $-0,09$ \\
$\begin{array}{l}\text { adaptivní } \\
\text { coping }\end{array}$ & $-0,03$ & 0,03 & $-0,11$ & 0,09 & $-0,14^{*}$ & $-0,03$ \\
\hline$* p<0,05$ & & & & &
\end{tabular}

$* p<0,05$

\section{Diskuze}

Výzkum poukázal na pozitivní souvislost mezi vyhýbavostí ve vztahu $\mathrm{k}$ rodičům a copingovým repertoárem. Uvedené zjištění je tak v rozporu s výsledky studie Schmidtové et al. (2002), která mezi vyhýbavostí a repertoárem copingových strategií objevila negativní vztah. Na výsledek, že s rostoucí vyhýbavostí ve vztahu k rodičům se zvětšuje i repertoár copingových strategií, lze pohlížet i z vývojového hlediska. Tato souvislost totiž nebyla nalezena ve vztahu k partnerovi. Na to, že rodiče svým chováním přispívají k rozvoji copingových zdrojů dětí, poukazují i Skinnerová a ZimmerGembecková (2007). Je tedy možné, že vyhýbavost v citové vazbě s rodiči vede k osvojení většího počtu copingových strategií, které nepředpokládají pomoc či jakoukoli jinou účast dalších osob. Tím, že se jedinci vyhýbají rodičům, spoléhají se více na sebe, mají větší potřebu osvojit si jiné, vlastní způsoby, kterými nahrazují pomoc nebo oporu od rodičů.

Rozsáhlejší repertoár u vyhýbavých jedinců však nutně neznamená, že dovedou způsoby zvládání efektivně využívat, další zjištění totiž poukázalo na negativní vztah mezi vyhýbavostí ve vztahu k otci a zapojováním alternativních strategií (adaptivní coping). Jedno z možných vysvětlení lze spatřit v tom, že hledání alternativních strategií by mohlo narušit představu vlastní dokonalosti, kterou si podle Mikulincera a Shavera (2007) snaží vyhýbavější jedinci utvářet a udržovat. Kdyby začali uvažovat nad alternativními způsoby zvládání, mohlo by to naznačit, že někde udělali chybu a že ji připouští, a narušit jim to tak jejich sebepojetí, které se snaží chránit. 

stresu a používáním copingových strategií

To, že větší copingový repertoár nutně neznamená jeho efektivnější využívání, podporuje i zjištění o nulovém vztahu mezi repertoárem a copingovou flexibilitou. Tento jev může být způsoben tím, že flexibilita ve zvládání stresu potažmo adaptivní coping je pojímána jako proces (Kato, 2012), ale repertoár copingových strategií je spíše rezervoár možností, které mohou i nemusí být využity. Může také docházet $\mathrm{k}$ tomu, že jedinec zapojuje více způsobů z repertoáru najednou, a nikoli že zapojuje další, až když zjistí, že jedna strategie nefunguje, jak je tomu v pojetí Katoa (2012). Zde lze spatřit možnost pro aplikaci výsledků do praxe poradců či psychoterapeutů, ti by se mohli snažit pomoci klientům $\mathrm{s}$ vyšší mírou vyhýbavosti ve vztahu k rodičům efektivněji a flexibilněji využívat jejich větší repertoár strategií.

Předpoklad, že je repertoár copingových strategií mediátorem vztahu mezi citovou vazbou a vnímáním stresu, se nepodařilo prokázat. Jedno z možných vysvětlení spočívá v tom, že vztahy byly prověřovány na obecné úrovni pomocí hodnot průměrujících všechny vybrané situace. Proto se domníváme, že by bylo př́nosné prozkoumat souvislosti i na úrovni jednotlivých situací.

Při interpretaci výsledků je potřeba vzít v potaz nevyváženost zkoumaného vzorku, podíl mužů je totiž přibližně $20 \%$. Pravděpodobně je to způsobeno tím, že cílová populace byla oslovována pomocí internetu a sociálních sítí. S podobným problémem se potýkali i jiní výzkumníci, kteří realizovali své studie prostřednictvím internetu (např. Fraley et al., 2011). Možnosti, že podíl mužů ve výzkumném vzorku bude menší, jsme si byly vědomy ještě před zahájením sběru dat. Proto jsme se rozdílu snažily zamezit cíleným oslovováním portálů, kde se muži vyskytují ve větším počtu (např. diskuzní fórum Vysokého učení technického v Brně). Přesto se nepodařilo skupiny pohlaví ani přibližně vyrovnat. Menší ochota mužů vyplnit dotazník může být způsobena i tím, že měli odpovídat na otázky spojené s blízkými vztahy, což jim mohlo být nepř́íjemnější než ženám.

Jisté omezení mohou představovat i hypotetické stresové situace, které byly použity v rámci metody zjišt'ující repertoár copingových strategií a vnímání stresu. Pro některé respondenty mohly být představované situace těžko představitelné, $v$ takovém prŕpadě to však u dané situace mohli uvést. Hypotetické situace jsme zvolily z toho důvodu, že všichni respondenti byli vystaveni stejným situacím, bylo tak možno lépe porovnat jejich vnímání míry stresu v daných situacích.

Další výzkumné projekty by se mohly zaměřit i na podrobnější prozkoumání souvislosti repertoáru copingových strategií a flexibility ve zvládání stresu, aby tak mohly potvrdit či vyvrátit, zda spolu tyto jevy opravdu nesouvisí, jak se ukázalo v tomto výzkumu. Domníváme se, že by bylo př́nosné i detailnější zkoumání vztahů mezi citovovu vazbou, repertoárem copingových strategií a vnímáním stresu na úrovni jednotlivých situací, eventuálně toho, zda ve vztahu mezi citovou vazbou a vnímáním stresu nehraje roli flexibilita ve zvládání stresu. Př́padná zjištění by opět mohla mít svou aplikační hodnotu v praxi. 
M. Rod'anová \& L. Lacinová: Možné souvislosti mezi blízkými vztahy vysokoškolských studentů, vnímáním stresu a používáním copingových strategií

\section{Literatura}

Bowlby, J. (1969/2010). Vazba: Teorie kvality raných vztahů mezi matkou dítětem. Praha: Portál.

Brennan, K. A., Clark, C. L., \& Shaver, P. R. (1998). Self-report measurement of adult romantic attachment: An integrative overview. In J. A. Simpson \& W. S. Rholes (Eds.), Attachment theory and close relationships (s. 46-76). New York: Guilford Press.

Buelow, S. A., Lyddon, W. J., \& Johnson, J. T. (2002). Client attachment and coping resources. Counselling Psychology Quarterly, 15(2), 145-152. Staženo dne 30. záŕí 2012 na http://search.ebscohost.com

Fraley, R., Heffernan, M. E., Vicary, A. M., \& Brumbaugh, C. (2011). The Experiences in Close Relationships-Relationship Structures Questionnaire: A method for assessing attachment orientations across relationships. Psychological Assessment, 23 (3), 615-625. Staženo dne 7. prosince 2012 na http://www.amandavicary.com/ECR-RS.pdf

Galatzer-Levy, I. R., Burton, C. L., \& Bonanno, G. A. (2012). Coping flexibility, potentially traumatic life events, and resilience: A prospective study of college student adjustment. Journal of Social and Clinical Psychology, 31 (6), 542-567. Staženo dne 23. ř́jna 2012 na http://search.ebscohost.com

Kato, T. (2012). Development of the Coping Flexibility Scale: Evidence for the Coping Flexibility Hypothesis. Journal Of Counseling Psychology, 59(2), 262-273. Staženo dne 23. řijna 2012 na http://search.ebscohost.com

Kenny, D. A. (2012, 3. dubna). Mediation. Staženo dne 10. dubna 2013 na http://www.davidakenny.net/cm/mediate.htm

Lazarus, R., \& Folkman, S. (1984). Stress, Appraisal, and Coping. New York: Springer Publishing Company.

McCarthy, C., Moller, N., \& Fouladi, R. (2001). Continued attachment to parents: Its relationship to affect regulation and perceived stress among college students. Measurement and Evaluation in Counseling and Development, 33 (4), 198-213. Staženo dne 11. února 2013 na http://search.ebscohost.com

Mikulincer, M. (1997). Adult attachment and information processing: Individual differences in curiosity and cognitive closure. Journal of Personality and Social Psychology, 72 (5), 12171230.

Mikulincer, M., \& Shaver, P. (2007). Attachment in adulthood: structure, dynamics, and change. (xii, 578 p.) New York: Guilford Press.

Ognibene, T. C., \& Collins, N. L. (1998). Adult attachment styles, perceived social support and coping strategies. Journal of Social and Personality Relationships, 15 (3), 323-345.

Reiner, S. R., Anderson, T. L., Hall, M., \& Hall, T. W. (2010). Adult attachment, God attachment and gender in relation to perceived stress. Journal of Psychology and Theology, 38 (3), 175-185. Staženo dne 2. ř́jna 2012 na http://search.ebscohost.com

Roussi, P., Krikeli, V., Hatzidimitriou, C., \& Koutri, I. (2007). Patterns of coping, flexibility in coping and psychological distress in women diagnosed with breast cancer. Cognitive Therapy and Research, 31 (1), 97-109. Staženo dne 23. ř́jna 2012 na http://search.ebscohost.com 
Schmidt, S., Nachtigall, C., Wuethrich-Martone, O., \& Strauss, B. (2002). Attachment and coping with chronic disease. Journal Of Psychosomatic Research, 53(3), 763-773.

Skinner, E. A., \& Zimmer-Gembeck, M. J. (2007). The development of coping. Annual Review of Psychology, 58, 119-144. Staženo 23. ř́ina 2012 na http://arjournals.annulareviews.org

\section{Rod'anová, M., \& Lacinová, L. (2015): Attachment in college students, stress appraisal and coping}

The aim of the empirical study was to determine whether anxiety/avoidance with mother, father and partner is related to coping strategies repertoire and to coping flexibility. Another aim was to determine whether the coping strategies repertoire mediate the relationship between attachment in adulthood and stress appraisal. The research sample included 417 college students from 19 to 30 years old. Coping strategy repertoire and stress appraisal were assessed by personally-designed set of vignettes. Coping flexibility was measured by Coping Flexibility Scale (Kato, 2012) and attachment was assessed by Relationship Structures Questionnaire (ECR-RS; Fraley et al., 2011). Regression analysis discovered the positive relationship between avoidance with parents and coping strategies repertoire and negative relationship between avoidance with father and adaptive coping. Coping strategies repertoire did not mediate the relationship between attachment in adulthood and stress appraisal.

Keywords: attachment in adulthood, anxiety, avoidance, stress appraisal, coping. 